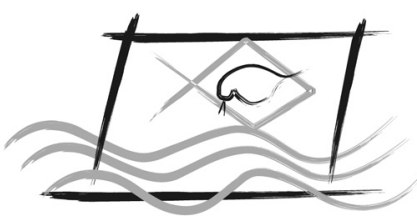

ECOTOX - BRASIL

\title{
What is the best buffer for preservation of cells in vitro: a standardization for gill cells in order to use in the Comet Assay
}

\author{
N.C. Ghisi ${ }^{1 *}$, W.A. Ramsdorf ${ }^{2} \&$ M.M. Cestari ${ }^{3}$ \\ 1Programa de Pós-Graduação em Ecologia de Ambientes Aquáticos Continentais (PEA), Universidade Estadual de Maringá (UEM), \\ Av. Colombo, 5790, Bloco G-90, sala 16, Jardim Universitário, CEP:87020-900, Maringá, Paraná, Brasil \\ ${ }^{2}$ Departamento de Química e Biologia, Universidade Tecnológica Federal do Paraná (UTFPR), \\ Rua Deputado Heitor de Alencar Furtado, 4900, Bloco C, Ecoville, CEP: 81280-340, Curitiba, Paraná, Brasil \\ ${ }^{3}$ Departamento de Genética, Universidade Federal do Paraná (UFPR), Centro Politécnico. Jardim das Américas, \\ CEP: 81531990, P.O. Box: 19071, Curitiba, Paraná, Brasil.
}

(Received October 05, 2012; Accept March 08, 2013)

\begin{abstract}
The Comet Assay is a rapid and sensitive method for detection of breaks in the DNA strand into individual cells, commonly used at ecotoxicology. At this time, the method has been refined, but not yet fully standardized and variations on protocol are common. When environmental reviews are performed, the large number of samples required and the conditions of handling during transportation of samples to the laboratory are frequent problems. Until now, however, no truly effective method for samples preservation for this test was described. Therefore, we tested three stock solutions: fetal bovine serum (FBS), phosphate buffered saline (PBS) e Tris. Gill cells of Rhamdia quelen contaminated with insecticide Fipronil were maintained in these solutions, for 0,24 and 48 hours to perform Comet Assay. It was found that fetal bovine serum was the solution that best preserved the DNA integrity of gill cells, followed by Tris and finally by PBS. We concluded in this study that fetal bovine serum is the solution that best conserve the gill cells and genetic material of $R$. quelen for a time until 48 hours in the absence of light and at $4^{\circ} \mathrm{C}$.
\end{abstract}

Keywords: cell viability, single cell gel electrophoresis, fish, Rhamdia quelen, fetal bovine serum.

\section{Qual é o melhor tampão oara preservação de células in vitro: Uma padronização para células de brânquia para uso no Ensaio Cometa}

\section{Resumo}

O Ensaio Cometa é um método sensível e rápido para detectar quebras na fita de DNA em células individuais, muito usado em pesquisas ecotoxicológicas. Desde sua criação em 1984, o método foi aperfeiçoado, mas ainda não completamente padronizado, sendo variações de protocolo frequentes. Quando análises ambientais são realizadas, o elevado número de amostras requerido e as condições de manuseio durante o transporte ao laboratório são problemas comuns. Até agora, todavia, nenhuma metodologia realmente eficiente para preservação de amostras para este ensaio foi descrita. Por isto, testamos três soluções de estoque de células: soro bovino fetal (FBS), tampão fosfato salino (PBS) e Tris. Células branquiais de Rhamdia quelen contaminado com Fipronil foram conservadas nestas soluções por tempos de 0, 24 e 48 horas, para realização do Ensaio Cometa. Obteve-se que o FBS foi a substância que melhor preservou o DNA das células, seguido pelo Tris e por último pelo PBS. Conclui-se neste trabalho, que o soro bovino fetal é a solução mais eficiente na conservação da integridade do DNA das células branquiais de $R$. quelen, em qualquer grupo de exposição ao contaminante ou controle. Recomenda-se então a preservação de células no soro bovino fetal, mantendo-as em $4^{\circ} \mathrm{C}$ e na ausência de luz, quando não é possível a preparação imediata das amostras até 48 após a retirada do tecido.

Palavras chave: viabilidade celular, eletroforese em gel com células individuais, peixes, Rhamdia quelen, Soro bovino fetal.

*Corresponding author: Nédia de Castilhos Ghisi; e-mail: nediaghisi@gmail.com 


\section{INTRODUCTION}

The Comet Assay is a good genotoxicity assay, since it represents a rapid, sensitive and inexpensive method for measuring visual evidences of DNA damage in individual cells. Additionally, it can be conducted on virtually any eukaryotic cell type, in vivo as well as in vitro. It allows the detection of DNA strand breaks and alkali-labile sites by measuring the migration of DNA fragments from immobilized nuclear DNA. This assay has gained widespread use in various areas including biomonitoring, genotoxicology, ecological monitoring and as a tool for research into DNA damage or repair in different cell types in response to a range of DNAdamaging agents (Liao et al., 2009).

The Comet Assay, which is also referred to as the single cell gel electrophoresis assay (SCG or SCGE assay), was primarily applied for ecotoxicology about fifteen years ago, and become one of the most popular tests to detect strand break on aquatic animals both in vitro, in vivo or in situ exposure (Ohe et al., 2004).

Because the Comet Assay analyzes the cells individually, there are some limitations in tissue disintegrate. The cells should be dissociated for fragmentations process or through enzymes action. This cell must be conveniently separated by a way that do not cause damage to they, but allows their individualization. The cells could be diluted in fetal bovine serum, physiological solution, RPMI (Roswell Park Memorial Institute medium) or other solutions. Independently of the used medium, the cell processing must necessarily ensure the minimum of DNA damage (Ferraro, 2003).

Thus, the preservation of biological samples is a fundamental step. Unfortunately, this procedure often may results on several levels of artifacts (Dubochet \& Sartori-Blanc, 2001). When environmental assessments are performed, the great samples quantity needed and the handling during the transporting are common difficulty.

Some studies have suggest the possibility of storing slides for periods up to four months in lysis buffer solution (Nacci et al., 1996). On the other hand, studies have shown a possible effect of storing slides in lysis solution for a prolonged period, which produces changes in the Comet tail patterns (Belpaeme et al., 1998). Even now, however, no really satisfactory methodology for samples preservation for Comet Assay was described (Ramsdorf et al. 2009).

Despite the few studies about this issue, among the used solutions to dissociate and preserve the cells, we can cite the Ethylenediaminetetraacetic acid (EDTA), the phosphate buffered saline (PBS), the fetal bovine serum, the RPMI medium, the Tris and others mediums.

EDTA is a polyamino carboxylic acid and colorless, water-soluble solid. Its usefulness arises because of its role as a hexadentate ligand and chelating agent in blood, i.e. its ability to "sequester" metal ions such as $\mathrm{Ca}^{2+}$ and $\mathrm{Fe}^{3+}$. But, it has been found to be both cytotoxic and weakly genotoxic in laboratory animals (Lanigan \& Yamarik, 2002).
The fetal bovine serum (FBS) has widely been used, to in vitro culture of embryos and cells. Gulve \& Dice (1989) found, for example, that FBS increased the rate of protein synthesis, and reduced the rate of protein degradation in rat skeletal muscle cells.

The fetal bovine serum is widely used for cellular culture and it has high concentration proteins, therefore it is a rich medium for cellular growth (Ramsdorf et al. 2009).

Tris (also known as THAM) is an abbreviation of the organic compound known as tris(hydroxymethyl)aminomethane, with the formula $\left(\mathrm{HOCH}_{2}\right)_{3} \mathrm{CNH}_{2}$. The $\mathrm{pH}$ of use of Tris (7-9) is the same of the most body fluids. This characteristic and its low cost transform the Tris in one of most extensively used buffers in biochemistry and molecular biology (Gomori, 1995). In biochemistry, Tris is widely used as a component of buffer solutions, such as in TAE and TBE buffer, especially for solutions of nucleic acids.

The phosphate buffered saline or PBS is a solution commonly used for biochemistry, but it has many other utilizations. It is the most common solution for dilution on Comet Assay, cited in numerous works: Masuda et al. (2004); Kim \& Hyun (2006); Deguchi et al. (2007); Bombail et al. (2001); Cavalcante et al. (2008).

There are yet other solutions for dilution, such as HBSS (Hank's Balanced Salt Solution associated with centrifugation for cell dissociation (Coughlan et al., 2002). The RPMI medium may be used as well. This is a mixture of enriched salts with amine acids, vitamins and essential components to cellular growth. There are authors using L-15 Medium (Leibovitz) (Boettcher et al., 2011). This was originally used to grow cell lines in the absence of $\mathrm{CO}_{2}$, requiring sodium bicarbonate. L-15 is buffered by its complement of salts, free base amino acids and galactose substituted for glucose to help maintain physiological $\mathrm{pH}$ control.

It is important to remember that the Comet Assay is fundamentally a comparative test. In this sense, there is necessary, at least, a negative control. There are no cells without DNA damage, since the self cellular metabolism can generate about 1000 diary injuries on DNA/cell. In this way, generally it should to module the technical conditions to a minimum of DNA to migrate from head to the tail in negative controls (Ribeiro et al., 2003) and that a minimum of spurious variables affect the DNA on every one treatment, contaminated and control groups.

In several studies, gill cells were used for SCGE assay as they are prone to injury caused by chemicals and xenobiotics (Nwani et al., 2011; Ahmed et al., 2011; Alink et al., 2007; Schnurstein \& Braunbeck, 2001). Gill cells are the most appropriate target organ that is directly and constantly exposed to the DNA damaging chemicals dissolved in water (Dzwonkowska \& Hubner, 1986).

Thus, it is important a standardization of a storing solution for cell that conserve for a longer time, without to do harm to DNA, and keep them qualified to analysis of Comet Assay and other tests. The aim of this work is to identify the best 
solution for maintaining the in vitro integrity of DNA of fish gill cell for a longer period, both in contaminated or negative control groups. For this, we will test three storing solutions: fetal bovine serum, Tris and the phosphate buffered saline, to conserve the gill cells of the neotropical fish Rhamdia quelen, contaminated with the pesticide Fipronil.

Fipronil is a broad use insecticide that belongs to the phenylpyrazole chemical family (PAN-UK, 2007). It is the active principle of the broad spectrum pesticides as Frontline $^{\circledR}$, Termidor ${ }^{\circledR}$ and, Top Spot $^{\circledR}$. Small concentrations of Fipronil are lethal to the most fish species until now tested, and especially toxic to juvenile fishes (Ohi et al., 2004). There are some studies that research the lethal dose of fipronil to fishes. Toxicity of fipronil to fish varies with species. It is very highly toxic to bluegill sunfish, Lepomis macrochirus, $\left(\mathrm{LC}_{50}\right.$ (Lethal Concentration) $\left.(96 \mathrm{~h})=85 \mu \mathrm{g} \mathrm{L} \mathrm{L}^{-1}\right)$, highly toxic to rainbow trout $\left(\mathrm{LC}_{50}(96 \mathrm{~h})=248 \mu \mathrm{g} \mathrm{L}^{-1}\right)$ and to European carp $\left(\mathrm{LC}_{50}(96 \mathrm{~h})=430 \mu \mathrm{g} \mathrm{L}^{-1}\right)$. It is very highly toxic to tilapia (Oreochromis niloticus) $\left(\mathrm{LC}_{50}(96 \mathrm{~h})=42 \mu \mathrm{g} \mathrm{L}^{-1}\right)$. Fipronil affects larval growth in rainbow trout at concentrations greater than $6.6 \mu \mathrm{g} \mathrm{L}^{-1}$ (PAN-UK, 2007).

\section{MATERIAL AND METHODS}

Rhamdia quelen (Teleostei, Heptapteridae), a neotropical fish popularly known as "Jundiá", was chosen for the bioassays. The choice of the specie was because this is a typical Neotropical fish, being promising specie to cultivation, with good adaptation to artificial conditions, like in laboratory. Moreover, about the feeding conditions, it is generalist (Gomes et al., 2000) and this characteristic contributes to its adaptation to artificial food, and its domestication. Several researches point this specie as very good bioindicator (Miron et al., 2005; Glusczak et al., 2007, Ghisi et al., 2011)

Groups with 15 animals were exposed to different doses of Fipronil (Termidor 25 EC - BASF S/A ${ }^{\circledR}$ ): 0.05, 0.10 and $0.23 \mu \mathrm{g} \mathrm{L}^{-1}$. A control group was kept unexposed (only filtered water). Each group was housed in a separate aquarium and acclimatized in aired tanks at constant water temperature $\left(22^{\circ} \mathrm{C}\right)$ under a 12 -h light/dark photoperiod. The animals had a mean weight of $37.4 \mathrm{~g}$ (standard deviation of $\pm 7 \mathrm{~g}$ ) and 17.3 $\mathrm{cm}$ in length (standard deviation of $\pm 1 \mathrm{~cm}$ ).

The reason for choosing the tested doses was based on: (1) the upper concentration permitted by European Community legislation which is $0.10 \mu \mathrm{g} \mathrm{L}^{-1}$, for all pesticides individually in water for human consumption (CEE 1980), (2) we used a concentration half that set by the European community $(0.05$ $\mu \mathrm{g} \mathrm{L}^{-1}$ ); and (3) $0.23 \mu \mathrm{g} \mathrm{L}^{-1}$ was the median concentration of Fipronil found at sampling sites in streams draining basins with intensive rice cultivation, so an realistic environmental concentration (Mize et al., 2008).

The contamination was a 60 days semi-static bioassay, i.e., one-third of the water was renewed every 48 hours. For dissection of the gills, each individual was anesthetized with $0.02 \%$ MS222 (ethyl-ester-3-aminobenzoic acid, Sigma) to avoid suffering. Our experiment was conducted in accordance with national and institutional guidelines for the protection of animal welfare from Brazilian College of Animal Experimentation - COBEA (COBEA- $\mathrm{http} / / / \mathrm{www}$.cobea.org. br/). It follows the Canadian Council on Animal Care - Guide for the Care and Use of Experimental Animals (Canadian Council on Animal Care, 2003).

The gills were divided in three parts, each one was put in a microtube with a different buffer solution: fetal bovine serum, Tris buffer and phosphate buffer saline. The Tris- $\mathrm{HCl}$ saccharose buffer (homogenization buffer) was prepared, in the same day of biological material collect: $17.1150 \mathrm{~g}$ de saccharose and $0.2422 \mathrm{~g}$ Tris, both dissolved in $100 \mathrm{ml}$ distilled water, correcting the $\mathrm{pH}$ to 8.6 with concentrated $\mathrm{HCl}$. This buffer was kept under refrigeration until the use.

For preparation of PBS we used: $0.2 \mathrm{~g} \mathrm{KCl}, 0.2 \mathrm{~g} \mathrm{KH}_{2} \mathrm{PO}_{4}$, $8 \mathrm{~g} \mathrm{NaCl}$ and $1.15 \mathrm{~g} \mathrm{Na}_{2} \mathrm{HPO}_{4}$ (anidre) dissolved in $1000 \mathrm{ml}$ distilled water. The $\mathrm{pH}$ was corrected to 7.4. The fetal bovine serum was used from Invitrogen ${ }^{\circledR}$.

The gill was kept in the solutions for the times 0 hour, 24 hours and 48 hours. After each time, the gill cells used for the Comet Assay were homogenized (Potter-type homogenizer at $1,500 \mathrm{rpm}$ ), and was collected a $10 \mu 1$ sample of cell suspension. Whit this samples we follow the Comet Assay with gills according to Speit \& Hartmann (1999), with modifications of Ferraro et al. (2004) and Cestari et al. (2004).

Comets tails were scored using a Leica epifluorescence microscope. One hundred nucleoids from each fish were analyzed (Kobayashi et al. 1995) using the visual classification based on the migration of DNA fragments from class 0 (no visible damage), class 1 (little damage), class 2 (medium damage), class 3 (extensive damage) and class 4 (maximally damaged) nuclei. The score was calculated by multiplying the number of nuclei in a class by the class number.

Prior to the utilization of the parametric or nonparametric analyses of variance, the data were tested for normality through Shapiro-Wilk test and homogeneity of variances through Levene's test. The data showed normality and homogeneity of variances, thus the parametric analysis of variance was the chosen method, i.e. two-way ANOVA (Quinn \& Keough, 2002). With this, we tested: 1) the damage rate between different stocking buffers, independently of stocking time (measures of material conservation); 2) the DNA damage rate between storing solutions and the times (measure to detect which solution is better concerning the storing time). When significant differences were found, we used the posteriori test Least Significant Difference of Fisher (LSD). Continuous variables were transformed to square root to meet the assumptions of normality.

\section{RESULTS}

The figure 1 show a comparison of DNA damage rate among the three storing solutions, independently of the time. In the graphic is evident the lower damage rate of fetal bovine serum relative to others two buffers. 


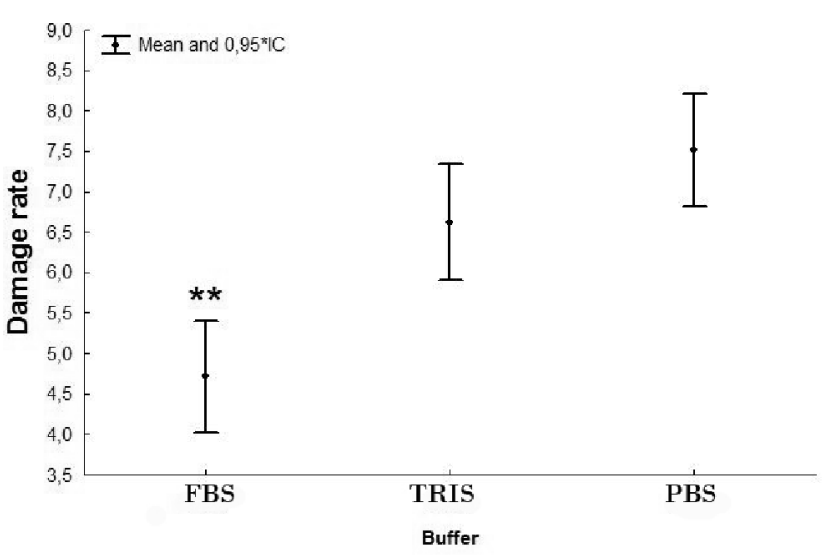

Figure 1- General comparison between the $\neg \neg \neg$ three buffers vs. damage rate, independently of time. $\mathrm{FBS}=$ fetal bovine serum; TRIS= Tris; PBS= phosphate buffered saline. The data are in square root. Note: $* *$ significant different group.

In the results of statistic analysis, showed in Table 1, we observe that the fetal bovine serum, invariably, has the lower DNA damage compared with Tris and PBS. The interaction between buffers and times was not significant $\left(\mathrm{F}_{4,88}=1,96 \mathrm{e} \mathrm{p}>0,05\right)$.

The table 2 shows the comparison between groups exposed to Fipronil and the time that samples are stocked in each buffer. We can see that, in almost all storing times tested, cells preserved in FBS have presented the lowest genetic material damage in comparison with others buffers. In the time zero, it is observed a more similarity among the solutions. But in the course of time, differences are emphasized. In general, the PBS shows the highest genetic damage rate, while samples conditioned in Tris present a middle genetic damage.

\section{DISCUSSION}

The Comet Assay was performed to evaluate possible DNA damage in piscine gill cells for the analysis of the optimal solution for sample conservation. We have tested three stocking buffers up 48 hours, and the statistic analysis detected significant differences among genetic damage rates of these. Our outcomes show a clear superior efficiency of fetal bovine serum to keep the DNA integrity. On the other hand, the phosphate buffered saline has presented the general highest genetic damage rate, while the Tris has intermediary conservation propriety. The results for exposure groups to fipronil vs. storing time has presented practically similar results for all treatments, i.e., the fetal bovine serum is more efficient buffer to preserve the DNA integrity.

In several studies, gill cells were used for SCGE assay as they are prone to injury caused by chemicals and xenobiotics (Nwani et al., 2011; Ahmed et al., 2011; Alink et al., 2007; Schnurstein \& Braunbeck, 2001). The evaluation of the gill cells integrity is important because this tissue is the primary sites of gas exchange, acid-base regulation, and ion transfer (Randall, 1990). The gills are essential for fish respiration and osmoregulation and also play a protective role. Because of their localization relatively external to environment and their large surface which are in direct and permanent contact with potential irritants, the gills are primary markers for aquatic pollution (Bernet et al. 1999).

Our result corroborates the study of Ramsdorf et al. (2009). In this, the Rhamdia quelen blood samples were preserved in three different solutions: fetal bovine serum, ethylenediaminetetracetic acid (EDTA) and PBS. Subsamples were collected after 0 hour, 24 hours, 48 hours and 72 hours, to perform the alkaline Comet Assay and flow cytometry. Their results also point to fetal bovine serum as the best solution to preserve the blood cells and their genetic material, followed by PBS, and finally the o EDTA.

The research of Ramsdorf et al. (2009) has tested the preservation of blood cell, while in the present study, we analyze de gill cells. The Comet Assay can be performed with several tissues, and different tissues can show different response due particular characteristic of each one (van der Oost et al., 2003). Thus, is also important to know the best

Table 1 - Comparison of damage rate among different buffers solutions into each Fipronil dose. F= two-way ANOVA results; LSD= Least Significant Difference of Fisher; * significant result $(\mathrm{p}<0.05) ; \mathrm{FBS}=$ fetal bovine serum; TRIS= Tris; PBS= phosphate buffered saline.

\begin{tabular}{|c|c|c|c|c|}
\hline Treatment & $F$ & & ISD (time) & \\
\hline Control & n. $s$. & $\frac{0 \text { hour }}{-}$ & $\frac{24 \text { hours }}{-}$ & $\frac{48 \text { hours }}{-}$ \\
\hline $0.05 \mu \mathrm{g} \mathrm{L}^{-1}$ & $\mathrm{~F}_{(4,110)}=5,42 *$ & $\mathrm{PBS}=\mathrm{TRIS}=\mathrm{FBS}$ & PBS $>$ TRIS,FBS & $\mathrm{PBS}=\mathrm{TRIS}=\mathrm{FBS}$ \\
\hline $0.10 \mu \mathrm{g} \mathrm{L}^{-1}$ & $\mathrm{~F}_{(4,126)}=5,63^{*}$ & $\mathrm{PBS}=\mathrm{TRIS}=\mathrm{FBS}$ & PBS $>$ TRIS,FBS & PBS $>$ TRIS $>$ FBS \\
\hline $0.23 \mu \mathrm{g} \mathrm{L}^{-1}$ & $\mathrm{~F}=5,30^{*}$ & PBS $>$ TRIS, FBS & PBS $>$ TRIS,FBS & PBS $>$ TRIS $>$ FBS \\
\hline
\end{tabular}

Table 2 - Comparison between different treatments (Fipronil doses) vs. stocking buffer vs. conservation time. $\mathrm{F}=$ two-way ANOVA results; LSD $=$ Least Significant Difference of Fisher; * significant result $(\mathrm{p}<0.05)$; n.s. = not significant; PBS= phosphate buffered saline; TRIS= Tris; FBS= fetal bovine serum.

\begin{tabular}{ccc}
\hline TREATMENT & \multicolumn{2}{c}{ Buffer } \\
\cline { 2 - 3 } Negative Control & $\mathrm{F}_{(2,89)}=29,37^{*}$ & PBS $>$ TRIS $>$ FBS \\
$0.05 \mu \mathrm{g} \mathrm{L}^{-1}$ & $\mathrm{~F}_{(2,110)}=11,44^{*}$ & PBS $>$ TRIS, FBS \\
$0.10 \mu \mathrm{g} \mathrm{L}^{-1}$ & $\mathrm{~F}_{(2,126)}=16,78^{*}$ & PBS $>$ TRIS $>$ FBS \\
$0.23 \mu \mathrm{g} \mathrm{L}^{-1}$ & $\mathrm{~F}_{(210)}=13,24^{*}$ & PBS $>$ TRIS $>$ FBS \\
\hline
\end{tabular}


buffer to preserve different cell types. In the present study, we also have tested animals exposed to a pesticide, to verify if in all treatment there are homogeneity of DNA preservation.

The best results for the FBS in DNA conservation is attributed mainly to its composition. The serum is a rich source of proteins, growth factor, amino acids, carbohydrates, ions, vitamins and other compounds. Several components of the serum are likely beneficial for protecting the cell samples in the work. For example, the high concentration of glucose present in the FBS $(\sim 0.6-1.2 \mathrm{mg} / \mathrm{ml})$ (Maurer, 1986), could act as an energy source for cellular metabolism (Scott et al., 2005).

Hung et al. (2004) in their work conclude that fetal bovine serum suppresses apoptosis and protect the cells, delaying cell death. The presence of a protease inhibitor is mainly important because of its anti-trypsin activity, which prevents this enzyme to act against the cells. Furthermore, the osmolarity of the serum (322mM) (Maurer, 1986) is similar to that of the fish freshwater blood (Potts \& Parry, 1964), with which the gill cells have intimate contact.

The PBS is the most common solution for dilution on Comet Assay; nevertheless, studies show that PBS and Tris have negative effects to cells. Regarding Tris there are evidences of deleterious effects on growth and on content of chlorophyll and phycoerythrin from algae Gracilaria birdiae (Ursi et al., 2008). The cell kept in PBS show, significantly, more DNA damage than that kept in fetal bovine serum. This result may be related with the low osmolarity of PBS (149.14 mM) compared to that usually found in freshwater fishes (i.e. $292.5 \mathrm{mM}$ in Salmo truta) (Potts \& Parry, 1964). The difference between osmolarity of fish cells and PBS may have caused a water influx into the cells, causing injury to the nucleus (Ramsdorf et al. 2009).

Many research groups have put efforts in improving the usefulness of the Comet Assay in a wide range of research field. These developments resulted in a large number of different protocols, for the most part, modified methods of Singh et al. (1998) and Tice (1995). Consequently, interlaboratory comparisons are compromised by lack of standardization (Belpaeme et al., 1998).

The use of Comet Assay in field research commonly requires many samples. Thus, an effective method for samples preservation is a prerequisite to extend the application of this technique. Two techniques were studied, the cryopreservation and the storing slides in lysis buffer. Nacci et al. (1996) have storing slides with cells for until four months in lysis buffer. Although, reports have shown a possible effect of storing slides in lysis solution, i.e. changes in the Comet tail pattern in samples stored for a prolonged time. On the other hand, the cryopreservation has not showed efficient in cell preservation, but this is even more satisfactory in conservation of blood than to kidney and gill cells (Van der Elst, 1992).

Thus, we conclude in this work that the fetal bovine serum is the better storing solution to preserve gill cell and their genetic material of Rhamdia quelen, for times ranging from 0 to 48 hours, in absence of light and refrigerated at $4^{\circ} \mathrm{C}$. It is important to remember that this minimization of damage rate and increase on the safety conservation of cells is fundamental when we are comparing different groups of exposure to contaminants. This comparison is commonly the base of Comet Assay and other tests for assessment of xenobiontes effects.

This possibility of stocking the cells in microtubes for a longer time, especially when the researcher make field works or when there are so numerous samples, will become easier the procedures to Comet Assay, mainly as the immediate prepare of all samples are not possible.

\section{ACKNOWLEDGEMENTS}

The authors thank Aquatoxi group. This research was supported by CAPES (PROEX), an entity of the Brazilian Government towards the development of human resources.

\section{REFERENCES}

AHMED, M. K, HABIBULLAH-AL-MAMUN, M., HOSSAIN, M. A., ARIF, M., PARVIN, E., AKTER, M. S., KHAN, M. S. \& ISLAM, M. M., 2011, Assessing the genotoxic potentials of arsenic in tilapia (Oreochromis mossambicus) using alkaline and micronucleus test, Chemosphere, 84 (1):143-149. http://dx.doi. org/10.1016/j.chemosphere.2011.02.025

ALINK, G.M., QUIK, J.T.K., PENDERS, E.J.M., SPENKELINK, A., ROTTEVEEL, S.G.P., Maas, J.L., HOOGENBOEZEM, W., 2007, Genotoxic effects in the Eastern mudminnow (Umbra pygmaea L.) after exposure to Rhine water, as assessed by use of the SCE and Comet Assays: A comparison between 1978 and 2005. Mutat. Res., 63: 93-100. http://dx.doi.org/10.1016/j. mrgentox.2007.03.011

BELPAEME, K., COOREMAN, K. \& KIRSCH-VOLDERS, M., 1998, Development and validation of the in vivo alkaline Comet Assay for detecting genomic damage in marine flatfish. Mutat. Res., 415 (3):167-184. http://dx.doi.org/10.1016/S13835718(98)00062-X

BERNET, D., SCHMIDT, H., MEIER, W. \& WAHLI, T., 1999, Histopathology in fish: proposal for a protocol to assess aquatic pollution. J. Fish Diseases, 22: 25-34. http://dx.doi.org/10.1046/ j.1365-2761.1999.00134.x

BOETTCHER, M., GRUND, S., KEITER, S., KOSMEHL, T., REIFFERSCHEID, G., SEITZ, N., ROCHA, P. S., HOLLERT, H. \& BRAUNBECK, T., 2010, Comparison of in vitro and in situ genotoxicity in the Danube River by means of the Comet Assay and the micronucleus test. Mutat. Res., 700: 11-17. http://dx.doi. org/10.1016/j.mrgentox.2010.04.016

BOMBAIL, V., AW, D., GORDON, E. \& BATTY, J., 2001, Application of the Comet and Micronucleus Assays to butterfish (Pholis gunnellus) erythrocytes from the Firth of Forth, Scotland. Chemosphere, 44: 383-392. http://dx.doi.org/10.1016/S00456535(00)00300-3

CANADIAN COUNCIL ON ANIMAL CARE, 2003, Guidelines on: laboratory animal facilities - characteristics, design and development, Ottawa ON Canada, 115p. Available in http:// www.ccac.ca. Accessed 07 September 2011.

CAVAlCANTE, D. G. S. M., MARTINEZ, C. B. R. \& SOFIA, S. H., 2008, Genotoxic effects of Roundup ${ }^{\circledR}$ on the fish Prochilodus lineatus. Mutat. Res., 655: 41-46. http://dx.doi.org/10.1016/j. mrgentox.2008.06.010 
CEE - Comunidade Econômica Européia (1980). Directiva 80/778/ CEE relativa à qualidade de águas destinadas ao consumo humano. Jornal Oficial da Comunidade Européia, n.L299, 20p. Available in: http://eur-lex.europa.eu/LexUriServ/LexUriServ.do?uri=CEL EX:31998L0083:PT:HTML. Accessed in 10 March 2012.

CESTARI, M. M., LEMOS, P. M. M., OLIVEIRA - RIBEIRO, C. A., COSTA, J. R. M. A., PELletieR, E., FERRARO, M. V. M., MANTOVANI, M.S. \& FENOCCHIO, A. S., 2004, Genetic damage induced by trophic doses of lead in the neotropical fish Hoplias malabaricus (Characiformes, Erythrinidae) as reveled by the Comet Assay and chromosomal aberrations. Genet. Mol. Biol., 27 (2): 270-274. http://dx.doi.org/10.1590/S141547572004000200023.

COBEA - Colégio Brasileiro de Experimentação Animal, available in: http://www.cobea.org.br/; accessed in 28 February 2012.

COUGHLAN, B. M., HARTL, M. G. J., O'REILLY, S. J., SHEEHAN, D., MORTHERSILL, C., VAN PELT, F. N. A. M., O'HALLORAN, J. \& O'BRIEN, N. M., 2002, Detecting genotoxicity using the Comet Assay following chronic exposure of Manila clam Tapes semidecussatus to polluted estuarine sediments. Marine Poll. Bull., 44: 1359-1365. http://dx.doi. org/10.1016/S0025-326X(02)00254-0

DEGUCHI, Y., TOYOIZUMI, T., MASUDA, S., YASUHARA, A., MOHRI., S., YAMADA, M., INOUE, Y. \& KINAE, N., 2007, Evaluation of mutagenic activities of leachates in landfill sites by micronucleus test and Comet Assay using goldfish. Mutat. Res., 627: 178-185. http://dx.doi.org/10.1016/j. mrgentox.2006.11.006

DUBOCHET, J. \& SARTORI BLANC, N., 2001, The cell in absence of aggregation artifacts. Micron, 32(1): 91-99. http://dx.doi. org/10.1016/S0968-4328(00)00026-3

DZWONKOWSKA, A. \& HUBNER, H., 1986, Induction of chromosomal aberrations in the Syrian hamster by insecticides tested in vivo. Arch. Toxicol. 58: 152-156. http://dx.doi. org/10.1007/BF00340974

FERRARO, M. V. M., 2003, Avaliação do efeito mutagênico do tributilestanho (TBT) e do chumbo inorgânico (PbII) em Hoplias malabaricus (Pisces) através dos ensaios: Cometa, Micronúcleo e de Aberrações Cromossômicas. Dissertação de Mestrado, Universidade Federal do Paraná, Curitiba.

FERRARO, M. V., FENOCCHIO, A. S., MANTOVANI, M. S., CESTARI, M. M. \& RIBEIRO, C. A. O., 2004, Mutagenic effects of tributyltin (TBT) and inorganic lead (PbII) on the fish H. malabaricus as evaluated using the Comet Assay, Piscine Micronucleus and Chromosome Aberrations tests. Genet. Mol. Biol., 27(1): 103-107. http://dx.doi.org/10.1590/S141547572004000100017

GHISI, N. C., RAMSDORF, W. A.; FERRARO, M. V. M., ALMEIDA, M. I. M., OLIVEIRA-RIBEIRO, C. A., CESTARI, M. M., 2011, Evaluation of genotoxicity in Rhamdia quelen (Pisces, Siluriformes) after sub-chronic contamination with Fipronil. Env. Monit. Ass., 180(1-4): 589-99. http://dx.doi. org/10.1007/s10661-010-1807-7 123

GLUSCZAK, L., MIRON, S., MORAES, B. S., SIMÕES, R. R., SCHETINGER, M. R. C., MORSCH, V. M., LORO, V. L., 2007, Acute effects of glyphosate herbicide on metabolic and enzymatic parameters of silver catfish (Rhamdia quelen). Comparat. Bioch. Physiol., 146: 519-524. http://dx.doi.org/10.1016/j. cbpc.2007.06.004

GOMES, L. C., GOLOMBIESKI, J. I., GOMES, A. R. C., BALDISSEROTTO, B., 2000. Biologia do jundiá Rhamdia quelen (TELEOSTEI, PIMELODIDAE). Ciência Rural, 30 (1): 179-185. http://dx.doi.org/10.1590/S0103-84782000000100029
GOMORI, G., 1955, Preparation of Buffers for Use in Enzyme Studies. Meth. Enzymol., 1:138-146. Available in: http://2008. igem.org/wiki/images/8/84/Protein_Buffers.pdf. Accessed in 17 March 2013.

GULVE, E. A. \& DICE, J. F., 1989, Regulation of protein synthesis and degradation in LX myotubes. Biochem. J., 280: 377-387.

HUNG, W.T., CHEN, Y., TSENG, S. H., LI, H. L. \& CHEN, C. K., 2004, Fetal bovine serum suppresses apoptosis in the small intestine after total ischemia and reperfusion in mice. Journal of Pediatric Surgery, 39 (7):1077-1083. http://dx.doi.org/10.1016/j. jpedsurg.2004.03.047

KIM I.Y., HYUN C.K., 2006, Comparative evaluation of the alkaline comet assay with the micronucleus test for genotoxicity monitoring using aquatic organisms. Ecotoxicol Environ Saf., 64(3):288-97. http://dx.doi.org/10.1016/j.ecoenv.2005.05.019

LANIGAN, R.S. \& YAMARIK, T.A., 2002, Final report on the safety assessment of EDTA, calcium disodium EDTA, diammonium EDTA, dipotassium EDTA, disodium EDTA, TEA-EDTA, tetrasodium EDTA, tripotassium EDTA, trisodium EDTA, HEDTA, and trisodium HEDTA. Int. J. Toxicol. 21 (2): 95-142. http://dx.doi.org/10.1080/10915810290096522

LIAO, W., MCNUTT, M. A. \& ZHU, W. G., 2009, The Comet Assay: A sensitive method for detecting DNA damage in individual cells. Methods, 48: 46-53. http://dx.doi.org/10.1016/j. ymeth.2009.02.016

MASUDA, S., DEGUCHI, Y., MASUDA, Y., WATANABE, T., NUKAYA, H., TERAO, Y., TAKAMURA, T., WAKABAYASHI, K. \& KINAE, N., 2004, Genotoxicity of 2-[2-(acetylamino)-4[bis(2-hydroxyethyl)amino]-5-methoxyphenyl]-5-amino-7- bromo4-chloro-2H-benzotriazole (PBTA-6) and 4-amino-3,3-dichloro5,4-dinitro-biphenyl (ADDB) in goldfish (Carassius auratus) using the micronucleus test and the Comet Assay, Mutat. Res., 560: 33-40. http://dx.doi.org/10.1016/j.mrgentox.2004.02.005

MAURER, H. R., 1986, Towards chemically-defined, serum-free media for mammalian cell culture, p.13-30, In: R.I. FRESHNEY (Ed.), Animal Cell Culture: A Practical Approach, Oxford, IRL Press, 315p.

MIRON, D. S., SHETTINGER, M. R., MORSCH, V. M., BALDISSEROTTO, B., TIERNO, M. A., MORAES, G. \& VIEIRA, V. L. P., (2005), Effects of the herbicides clomazone, quinclorac, and metsulfuron methyl on acetylcholinesterase activity in the silver catfish (Rhamdia quelen) (Heptapteridae). Ecotox. Env. Saf., 61: 398-403. http://dx.doi.org/10.1016/j. ecoenv.2004.12.019

MIZE, S. V., PORTER, S. D., \& DEMCHECK, D. K., 2008, Influence of Fipronil compounds and rice-cultivation land-use intensity on macroinvertebrate communities in streams of southwestern Louisiana, USA. Environ. Poll., 152:491-503. http://dx.doi. org/10.1016/j.envpol.2007.03.021

NACCI, D.E., CAYULA S. \& JACKIM E., 1996, Detection of DNA damage in individual cells from marine organisms using the single cell gel assay, Aquat. Toxicol., 35: 197-210. http://dx.doi. org/10.1016/0166-445X(96)00016-1

NWANI, C.D., NAGPURE N.S., KUMAR, R., KUSHWAHA, B., KUMAR, P. \& LAKRA, W.S., 2011, Mutagenic and genotoxic assessment of atrazine-based herbicide to freshwater fish Channa punctatus (Bloch) using micronucleus test and single cell gel electrophoresis, Environ. Toxicol. Pharmacol., 31: 314-322. http://dx.doi.org/10.1016/j.etap.2010.12.001

OHE, T., WATANABE, T. \& WAKABAYASHI, K., 2004, Mutagens in surface waters: a review. Mutat. Res., 567:109-149. http://dx.doi.org/10.1016/j.mrrev.2004.08.003

OHI, M., DALSENTER, P.R., ANDRADE, A. J.M., NASCIMENTO, A. J., 2004, Reproductive adverse effects of fipronil in Wistar 
rats. Toxicol. Letters, 146: 121-127. http://dx.doi.org/10.1016/j. toxlet.2003.08.008

PAN-UK. Available in: http://www.pan-uk.org/pestnews/actives/ fipronil.htm. Accessed in 29 March 2012.

POTTS, W. T. W. \& PARRY, G., 1964, Osmotic and Ionic Regulation in Animals, Pergamon, Oxford, $423 \mathrm{pp}$.

QUINN, G. P. \& KEOUGH, M. J., 2002, Experimental design and data analysis for biologists. Cambridge University Press, Cambridge. 537p.

RAMSDORF, W. A., GUIMARÃES, F. S. F., FERRARO, M. V. M., GABARDO, J., TRINDADE, E. S. \& CESTARI, M. M., 2009, Establishment of experimental conditions for preserving samples of fish blood for analysis with both Comet Assay and flow cytometry. Mutat. Res., 673: 78-81. http://dx.doi.org/10.1016/j. mrgentox.2008.11.010

RANDALL, D.J., 1990, Control and co-ordination of gas exchange in water breathers. Adv. Comp. Environ. Physiol. 6:253-278. http://dx.doi.org/10.1007/978-3-642-75380-0 8

RIBEIRO, L. R., SALVADORI, D. M. F. \& MARQUES, E. K., 2003, Mutagênese ambiental, Editora ULBRA, Canoas. 355p.

SCHNURSTEIN, A. \& BRAUNBECK, T., 2001, Tail Moment $v$. Tail Length - Application of an In Vitro Version of the Comet Assay in Biomonitoring for Genotoxicity in Native Surface Waters Using Primary Hepatocytes and Gill Cells from Zebrafish (Danio rerio), Ecotoxicol. Environ. Saf. 49:187-196. http:// dx.doi.org/10.1006/eesa.2001.2050

SCOTT K.L., LECAK, J. \& ACKER, J.P., 2005, Biopreservation of red blood cells: past, present, and future, Transf. Med. Rev. 19 (2): 127-142. http://dx.doi.org/10.1016/j.tmrv.2004.11.004

SINGH, N. P., MCCOY, M. T., TICE, R. R. \& SCHNEIDER, E. L., 1988, A simple technique for quantification of low levels of DNA damage in individual cells. Experimental Cell Res., 175: 184-191. http://dx.doi.org/10.1016/0014-4827(88)90265-0

SPEIT, G. \& HARTMANN, A., 1999, The Comet Assay (single cell gel test), a sensitive test for the detection of DNA damage and repair. In D. S. Henderson (Ed.), Methods in molecular biology: DNA repair protocols - eukaryotic systems (pp. 203-211). Totowa: Human.

TICE, R., 1995, Protocol for the application of the alkaline single cell gel SCG. assay to the detection of DNA damage in mammalian cells, January 5. Available in: http://cometassay.com/Tice $\% 20$ and\%20Vasques.pdf, assessed in 13 March 2013.

URSI, S., GUIMARÃES, M. \& PLASTINO, E.M., 2008, Deleterious effect of TRIS buffer on growth rates and pigment content of Gracilaria birdiae Plastino \& E.C. Oliveira (Gracilariales, Rhodophyta), Acta Bot. Brasil., 22(3): 891-896. http://dx.doi. org/10.1590/S0102-33062008000300024

VAN DER ELST, J., 1992, Cryo-preservation of the mouse oocyte. Contribution to the study of cryo-preservation of mammalian oocytes, PhD Thesis, $243 \mathrm{p}$.

VAN DER OOST, R., BEYER, J., VERMEULEN, N. P. E., 2003, Fish bioaccumulation and biomarkers in environmental risk assessment: a review. Environ. Toxicol. Pharmacol. 13(2), 57149. http://dx.doi.org/10.1016/S1382-6689(02)00126-6 